\title{
WINNIPEG CHILD AND FAMILY SERVICES V. D.F.G.: a Commentary on the law, Reproductive Autonomy AND THE ALLURE OF TECHNOPOLICY
}

\author{
TIMOTHY CAULFIELd AND ERIN NELSON
}

\section{INTRODUCTION}

Few would dispute that the facts behind the Supreme Court decision in Winnipeg Child and Family Services v. D.F.G. ' are tragic. The welfare of a young woman, the health of that woman's unborn child, the role of the state in the realm of human reproduction, and the scope of the parens patriae jurisdiction, are all weighty concerns that made an unsatisfactory conclusion seem inevitable. As a result, the "leave it to the legislators" majority decision is hardly surprising. And, given that this remains a politically charged area of the law, there are reasons to be pleased with the immediate result of the case - the apparent recognition that interference with the autonomy of pregnant women is a serious step with profound implications and which should only be taken, if at all, after due consideration of all of the conflicting interests involved. Nevertheless, we have concerns about the reasoning employed in both McLachlin J.'s majority decision and in Major J.'s dissent. In particular, we feel that a number of the arguments articulated by Major J. - for example, his conclusion that science and medical technology have made the "born alive" rule irrelevant - have an intuitive appeal. As a result, it seems probable that these arguments will be reiterated in future cases.

Major J. relies on science to support much of his reasoning in this case. First, he places great weight upon material presented by interveners in relation to fetal alcohol syndrome (FAS), seeming to adopt uncritically the "facts" as presented. ${ }^{2}$ Second, Major J. relies on advances in medical technology to renounce the "born alive" rule for the purposes of the case at bar, terming the rule "a legal anachronism." 3 This unhesitating acceptance of scientific and technological knowledge raises squarely the question of the role of science in public policy and judicial decision making. This brief case comment seeks, in addressing this question, to dispel the allure of science as the driver of legal and social policy.

Our era is one in which breakthroughs in medical, genetic and reproductive technologies have become almost commonplace. Technology, for better or worse, is an

Timothy Caulfield, LL.M., Research Director, Assistant Professor, Health Law Institute, University of Alberta; Erin Nelson, LL.B., Project Manager, Health Law Institute. We would like to thank Nina Hawkins and Ted DeCoste, and the Alberta Heritage Foundation for Medical Research for its continued support.

[1997] S.C.J. No. 96 (QL) [hereinafter D.F.G.].

See infra note 31 and accompanying text.

D.F.G., supra note 1 at para. 102. 
integral part of western culture. ${ }^{4}$ From the spectre of human clones ${ }^{5}$ to the reality of pre-implementation genetic screening, ${ }^{6}$ science continues to reshape how we think about human reproduction. In such a constantly changing environment we need to be particularly careful how we choose to react to these advances in knowledge. Science should inform social policy, not direct it. Nor should the banner "scientific evidence" be used to support conclusions which are based primarily on ideology — particularly when the "evidence" presented is misleading, inaccurate, or incomplete. Ideally, empirical evidence, technological advances and medical breakthroughs should function as important elements of a broader interdisciplinary policy debate. ${ }^{7}$ Unfortunately, however, science can have a blinding effect. The enthusiasm which often surrounds technological breakthroughs or the emergence of new medical facts can obscure the relevant "non-scientific" principles - such as fundamental individual rights.

In Major J.'s dissent we see what could be considered the worst case scenario. His judgement is not, as one may think we are claiming, a simple reflexive response to the advances in medical knowledge surrounding reproduction. Rather, he turns to science in an almost ad hoc fashion - relying on empirical evidence when it supports undeveloped social policy conclusions but failing to consider the entire body of conflicting evidence (a body of evidence that needs to be carefully situated in the sociopolitical context of pregnancy). Worse yet, Major J.'s analysis does not even attempt to contemplate the broader implications of his conclusions, particularly in relation to the rapidly advancing nature of the very medical technology he relies on.

Given the lack of policy analysis in McLachlin J.'s reasons, and her comments regarding the role of the legislators, ${ }^{8}$ a comment on the integration of science and law, as set against the law's current respect for reproductive autonomy, seemed essential. McLachlin J.'s reasons do not go a great distance in giving policy makers any concrete factors to consider in drafting or debating legislation; as a result, it is conceivable that legislators will focus on Major J.'s dissent as a starting point, if not a foundation, for

For example, see N. Postman, Technopoly (New York: First Vintage Books, 1993) at 102: "The culture itself - its courts, its bureaucracies, its insurance systems, the training of doctors, patients' expectations - is organized to support technological treatments." See also, D. Nelkin \& M.S. Lindee, The DNA Mystique: The Gene as a Cultural Icon (New York: Freeman and Company, 1995). Some would go so far as to say that technology is an ideology, "so pervasive has it become in Western society": B. Katz Rothman, Recreating Motherhood: Ideology and Technology in a Patriarchal Society (New York: W.W. Norton \& Co., 1989) at 28.

A great deal has been written on human cloning. For an example, see Advisers to the President of the European Commission on the Ethical Implications of Biotechnology, "Ethical Aspects of Cloning Techniques" (1997) 23 Journal of Medical Ethics 349; and Executive Summary, Cloning Human Beings: The Report and Recommendations of the National Bioethics Advisory Commission (Rockland, Md., June 1997).

6 A. Mitchell, "Clinic to Sift Out Bad Genes" The Globe and Mail (24 September 1997) Al.

7. We recognize that judges can only work with the information which is provided by litigants, and that the litigants may not present all of the relevant information. This, however, does not justify judicial decision-making based on conflicting or incomplete evidence. Rather, where a decision involves weighing conflicting evidence and social policy considerations, the court ought to recognize its limitations and leave the decision to the legislators.

" To a large degree, McLachlin J.'s judgment is simply a reiteration of the commonly heard issues together with the conclusion that this is an area which should be addressed by legislators. 
policy formation in this area. This comment, therefore, is primarily a critical look at Major J.'s dissent, one which we hope will inform future debate and policy development around this politically-charged issue.

\title{
The Impact of Science on Social Policy
}

In a 1986 article on the effects of technology on the abortion debate, Daniel Callahan noted that scientific developments can "lead to a shift in public opinion, moral thinking, and court decisions." For example, advances in science can throw into doubt factual assumptions underlying earlier legal decisions; "motivate people to think in a different way about their beliefs"; create powerful "polemical advantages"; 10 and may "call attention to new considerations in fashioning a moral perspective." All of these influences are found in D.F.G. In particular, Major J.'s comments regarding the legal implications of "modern medical progress" to the relevance of the born alive rule highlight how science can facilitate a re-examination of past factual assumptions.

\begin{abstract}
We no longer need to cling to an evidentiary presumption to the contrary when technologies like real time ultra sound, fetal heart monitors and fetoscopy can clearly show us that a foetus is alive and has been or will be injured by the conduct of another. We can gauge fetal development with much more certainty than the common law presumed. How can the sophisticated micro-surgery that is now being performed on foetuses in utero be compatible with the "born alive" rule?"
\end{abstract}

Such a response to scientific developments is understandable. Science is capable of shedding light on areas once clothed in uncertainty and speculation. Indeed, in the discipline of law, which must continually struggle to derive solutions based on frustratingly inadequate information, the perceived certainty offered by science and technology provides a tempting substitute for thoughtful policy analysis. ${ }^{12}$ Yet, while it is always healthy to force "people to think in a different way about their beliefs," as science undoubtedly does, history has provided us with far too many examples as to why we should not react uncritically to new technological perspectives.

The "scientifically" based eugenic policies of the early twentieth century, which led to the passage of sterilization laws, serve as an extreme illustration of the need for caution. ${ }^{13}$ Eugenic policies were viewed as the necessary, moral and responsible

9 D. Callahan, "How Technology is Reframing the Abortion Debate" (1986) 16:1 Hastings Cent. Rep. 33 at 33.

10 For instance, Callahan concludes that: "Prolife activist groups believe that the scientific developments provide helpful ammunition, particularly in sensitizing the public to the fetus as a moral claimant" (ibid. at 39).

" D.F.G., supra note 1 at para. 109. For a review of international perspectives on this legal issue see A. Whitfield, "Common Law Duties to Unborn Children" (1993) 1 Medical L. Rev. 28.

12 Another example where the allure of "scientific certainty" is evident is the use of DNA paternity testing in the area of family law. See Goudie v. Goudie, [1993] B.C.J. No. 1049 (QL); G.L.K. v. J.K.H., [1995] M.J. No. 435 (Q.B.) (QL).

13 T. Caulfield \& G. Robertson, "Eugenic Policies in Alberta: From the Systematic to the Systemic?" (1996) 34 Alta. L. Rev. 59. For a discussion of similar issues from an American perspective, see S. Garcia, "Sociocultural and Legal Implications of Creating and Sustaining Life Through Biomedical Technology" (1996) $17 \mathrm{~J}$. of Legal Medicine 469 at 500-501. 
application of scientific knowledge. In a 1936 article supporting the mandatory sterilization of the "mentally unfit" the Lieutenant Governor of Ontario argued as follows:

There is no merit in allowing suffering of the kind I have described to you when it is borne by others than ourselves. The call comes down through the ages to our generation, to all of us here and now in Ontario, to save the many that are yet unborn from the lifelong misfortune which otherwise will certainly be theirs. Is there anything in the Christian faith which bids us turn a deaf ear to such a call? ${ }^{14}$

Of course, the ideology necessary to support the implementation of eugenic sterilization clearly existed before the claims of science found their way to practical application. However, as argued by many scholars, the social and political backdrop necessary for the inappropriate application of medical technology in the realm of reproduction has also existed for centuries. ${ }^{15}$ As such, there is no reason to presume that a legal rule, even one as seemingly value neutral as the "born alive" rule, can be discarded without serious consideration of its broader social and political ramifications. Even if the rule was once purely an evidentiary tool, as suggested by Major J., ${ }^{16}$ the current social context surrounding issues of fetal rights and reproductive autonomy infuse the born alive rule with broader implications - implications that the sophisticated advances of science, while not irrelevant, cannot, on their own, erase.

Major J.'s apparently casual dismissal of the "born alive" rule as evidentiary as opposed to substantive in nature gives rise to several questions. The one article he relies upon to support this conclusion situates the "born alive" rule in the context of the criminal law; in particular, the context of criminal acts committed by third parties (in other words, persons other than "the pregnant woman whose unborn child is killed"). ${ }^{17}$

H.A. Bruce, "Sterilization and the Problem of the Mentally Unfit",Maclean's Magazine (1 July 1936) 14 at 33. See also, "Sterilization Act Has Much Backing: List of Organizations Approving Principle of Bill is Tabled" Edmonton Journal (9 March 1928) 7. Similar pronouncements can be found in case law. For example, see the United States Supreme Court decision of Buck v. Bell, 274 U.S. 200 (1927).

As argued by J. Gallagher, "Collective Bad Faith: 'Protecting' the Fetus" in J.C. Callahan, ed., Reproduction, Ethics, and the Law: Feminist Perspectives (Bloomington: Indiana University Press, 1995) 343 at 345 :

The "fetal rights" phenomenon can be properly understood only in its social and political context. It emerges from a glorification of medical technology resulting in a distorted public view of it, combined with a sharp backlash against the women's movement, especially against the claim to reproductive freedom symbolized by the Roe $\mathbf{v}$. Wade abortion decision. The drive to assert legal rights for fetuses reflects a broader attempt to reassert male control over women and over reproduction itself.

16 D.F.G., supra note 1 at para. 92: "It has been submitted, however, that a foetus acquires no actionable rights in our law until it is born alive. In my view, the "born alive" rule, as it is known, is a common law evidentiary presumption rooted in rudimentary medical knowledge that has long since been overtaken by modem science and should be set aside for purpose of this appeal." other than criminal law. The point here, though, is that the author specifically narrows his argument to the case of criminal or tortious acts by third parties. In fact, the author makes the very point himself: 
Major J., however, does not appear to consider the relevance of context in respect of the "born alive" rule. Perhaps (although Major J. does not offer any), good reasons exist for abolishing the born alive rule in the criminal law setting in the case of a homicide charge, particularly where the technology exists to demonstrate that a stillborn fetus was alive in utero prior to the act of the accused. ${ }^{18}$ In that instance, it may not make sense to cling to a rule which would have the effect of denying the reality of the situation. What Major J. has not taken into consideration is that perhaps there are equally good or, arguably, better reasons for maintaining the rule as a substantive rule in other contexts. Indeed, there is an argument to be made that the criminal law context presents a very different set of factors than does the civil law context (for example, a personal injury claim). A fetus which has been harmed and consequently stillborn need not be alive or have an estate in order for criminal charges to be brought - rather, it is within the purview of the State to decide whether or not to proceed criminally. In the tort law context, by contrast, the person injured (or that person's estate) must bring the action - can (and should) a fetus that was never alive outside its mother's womb have an estate? How could we possibly hope to quantify the damages suffered - the destruction of any chance that fetus had at life itself - in such a case?

Aside from the questions that must be answered about the legal contexts in which the born alive rule may arise, there is a further issue that Major J., in deferring to the miracle of modern medical science, has utterly failed to consider. The fact that technology may obviate the need for reliance on the born alive rule does not, in itself, render irrelevant the policy reasons which may dictate its retention.

Even if Major $\mathrm{J}$. is correct in asserting that the "born alive" rule has been rendered superfluous by advances in medical technology, his disregard for the social context in which this appeal arises seems to be an alarming oversight. In our society, the sphere of decision making surrounding child-bearing and child-rearing is one into which the state is, rightly, very reluctant to enter. Canadian jurisprudence relating to medical

The principle that an unborn child is not a "person" within the language of the Fourteenth Amendment does not mean that a fetus may not be a human being or person in other contexts. So too, the principle that the unborn child does not have constitutional rights when balanced against the woman's constitutional right to privacy does not at all mean that the fetus may not have common law or statutory rights when balanced against the criminal acts of a third party.... Roe v. Wade is not directed to nonconsensual acts by third parties. It is not a bar to judicial or statutory recognition of the rights of the unborn child against tortious or criminal acts of third parties.

See C.D. Forsythe, "Homicide of the Unborn Child: The Born Alive Rule and Other Legal Anachronisms" (1987) 21 Valparaiso Univ. L. Rev. 563 at 618-19. Further, at 623, the author explains that his draft legislation (which would criminalize a variety of acts committed against the fetus) is not aimed at the conduct of the pregnant woman: "Throughout the legislation, "person" is defined to exclude "the pregnant woman whose unborn child is killed".... This exclusion would ... avert attacks on the legislation by those who might conceive that it would be applied against pregnant women who ingest alcohol, drugs, or tobacco during their pregnancy." 
decision-making demonstrates an unwavering commitment to the principle of autonomy, ${ }^{19}$ and the right to self-determination in the health care context finds resonance in judicial and academic commentary concerning procreative and parental liberty. ${ }^{20}$ It is in light of this recognition of autonomy as an integral aspect of the Canadian socio-political landscape that we must evaluate the propriety of compelling a woman to submit to an unwanted bodily intervention. Major J.'s decision fundamentally alters the existing socio-legal climate - he posits that interference with the pregnant woman is justified on the basis of what technology can do to protect the fetus within her. The point we wish to make is that whatever one's views about preferred outcomes in cases like this one, the fact of technological ability alone seems a very shaky foundation upon which to base such a profound change in the law. ${ }^{21}$

\section{SCIEnCe as a Guide to Social Policy: A CALl FOR A REASONED AND INTERdisciplinaRY APPROACH}

Used critically, empirical research can be an invaluable aid to the development of informed social policy. ${ }^{22}$ In fact, given the complexity of the dilemmas which flow from maternal/fetal conflict, a clear understanding of all the facts is essential. What is the impact of solvent abuse on fetal health? What social and environmental factors are relevant? What interventions are potentially effective? The answers to such questions, if available, are, of course, pertinent. They should not, however, be decisive.

See, for example, Malette v. Shulman (1990), 67 D.L.R. (4th) 321 (Ont. C.A.); Fleming v. Reid (1991), 82 D.L.R. (4th) 298 (Ont. C.A.); Ciarlariello v. Schacter, [1993] 2 S.C.R. 119.

E. (Mrs.) v. Eve, [1986] 2 S.C.R. 388 at 419-420; R. v. Morgentaler (1988), 44 D.L.R. (4th) 385 at 486 (per Wilson J.); M. Jackman, "The Canadian Charter as a Barrier to Unwanted Medical Treatment of Pregnant Women in the Interests of the Fetus" (1993) 14 Health L. Can. 49 [hereinafter "The Canadian Charter"]; M. Jackman, "The Constitution and the Regulation of New Reproductive Technologies" in Research Studies of the Royal Commission on New Reproductive Technologies: Overview of Legal Issues in New Reproductive Technologies, vol. 3 (Ottawa: Minister of Supply and Services Canada, 1993) 1; and B.R. v. Children's Aid Society of Metropolitan Toronto, [1995] I S.C.R. 315, where La Forest J. noted that s.7 of the Charter includes "a protected sphere of parental decision-making which is rooted in the presumption that parents should make important decisions regarding their children both because parents are more likely to appreciate the best interests of their children and because the state is ill-equipped to make such decisions itself."

This concern seems particularly relevant in light of the fact that disagreement about the best medical approach to widely varying situations are common, and "[e]ven where there is broad agreement about the necessity for treatment, judgments are not certain." L.M. Purdy, Reproducing Persons: Issues in Feminist Bioethics (Ithaca, N.Y.: Cornell University Press, 1996) at 96-97. Even the American Medical Association endorses education and communication over coercive action by physicians: American Medical Association, Report of the Board of Trustees, "Legal Interventions During Pregnancy: Court-Ordered Medical Treatments and Legal Penalties for Potentially Harmful Behaviour by Pregnant Women" (1990) 264(20) J.A.M.A. 2663. See also L. Woliver, "Reproductive Technologies, Surrogacy Arrangements, and the Politics of Motherhood" in M. A. Fineman \& I. Karpin, eds., Mothers in Law: Feminist Theory and the Legal Regulation of Motherhood (New York: Columbia University Press, 1995) 345 at 356, and infra note 31 and accompanying text. 
First, science rarely provides definitive conclusions - particularly in the realm of medicine. Because of the complexity of human biology, the unpredictability of human behaviour, and the innumerable compounding variables, the scientific "facts" relevant to health care are often not conclusive. Second, we must be sensitive to the evolving nature of scientific knowledge. Today's medical fact often becomes tomorrow's medical error. ${ }^{23}$ Third, despite the goal of objectivity, the accumulation and reporting of scientific evidence is, like most human endeavours, imbued with human values and ideology. ${ }^{24}$ As such, the relevance of scientific and technological developments must be considered with regard to the context from which they emerged. We need to be conscious of the reality that we live in a society in which the view of health care is still heavily influenced by the medical model. ${ }^{25}$ This raises two concerns: are we allowing science to obscure the broader social factors relevant to fetal health and are we turning to science for a "quick fix" to an infinitely complex dilemma? ${ }^{26}$ Fourth, and perhaps most importantly, there may be other policy considerations which should not be overthrown simply as a result of the existence of new medical evidence. That is, law should not abdicate its responsibility to science. ${ }^{27}$

B. Katz Rothman, "Commentary: When a Pregnant Women Endangers Her Fetus" (1986) 16 Hastings Cent. Rep. 25 at 25: "[O]bstetrics has too long a history of errors in management for us to be certain that obstetricians always know the best interests of the fetus." Indeed, the use of thalidomide for morning sickness, which is ironically referenced by Major, is but one example: D.F.G., supra note 1 at para. 123. See also Purdy, supra note 21 at 96-98; Woliver, supra note 21 and "The Canadian Charter," supra note 20 at 55.

The interplay between science, values and social policy is obviously a complex issue which is beyond the scope of this short piece. See generally, A. Ross, ed., Science Wars (Durham: Duke University Press, 1996). See also: Green, supra note 22 at 384; S. Jasanoff, "What Judges Should Know About the Sociology of Science" (1992) 32 Jurimetrics J. 345 at 347.

See, for example, Woliver, supra note 21 at 347: "A biological paradigm frames the issue medically and individually while distracting from the political and economic context of reproductive decisions. Medical technology, rather than social change, therefore is offered as the solution to reproductive problems and concerns." See also, A. Lippman, "Never Too Late': Biotechnology, Women and Reproduction" (1995) 40 McGill L.J. 875; and Royal Commission on New Reproductive Technologies, Proceed with Care: Final Report of the Royal Commission on New Reproductive Technologies (Ottawa: Minister of Supply and Services Canada, 1993) at 33: "One challenge that lies ahead is to increase scientific understanding of reproductive concerns while situating issues of reproductive technology in a larger social context and safeguarding women's personal control over issues that affect them directly and significantly." Woliver, ibid. at 359, argues that "[i]n addition to the marginalization of women in these reproductive arrangements, these technologies deflect pressures for social reforms by promising technological fixes for reproductive difficulties."

In commenting upon proposed legislation concerning abortion and, in particular, dealing with the question of when life begins, Mary Seger observed:

That the original framers of s. 158 thought science could resolve conclusively the question of the legal status of the unborn indicates perhaps a simplistic faith in the powers of modern science. As Harriet Meyer has noted, "Science, with its appearance of objectivity and its seemingly clear worldview, sometimes appeals to those trying to draw difficult lines." The scientific imprimatur may be especially appealing to politicians, administrators and other decision makers, since they can appeal to "outside experts" to justify their decisions.

M.C. Seger, "Can Congress Settle the Abortion Issue?" (1982) 12:3 Hastings Cent. Rep. 20 at 21. 
How does Major J. integrate scientific developments with policy considerations? Does he situate the advances of modern medicine in a broader social context? In a word, no. Indeed, despite frequent reference to various technologies, medical breakthroughs and empirical evidence, there is no critical analysis of the scientific conclusions on which he so heavily relies. ${ }^{28}$ For example, although Major $\mathrm{J}$. was willing to turn to the use of emerging medical knowledge concerning fetal health in order to buttress the arguments favouring intervention, he ignores (as the popular media often does) what science truly tells us (or can't tell us) about the effects of teratogenic substances. Major J. summarizes the findings in this area thus: "There is clear and overwhelming evidence that abuse of substances (alcohol, solvents, gasoline, etc.) by pregnant women can lead to fetal alcohol syndrome or fetal alcohol effects." ${ }^{29}$ However, as noted by numerous commentators, there are many unanswered questions concerning the relationship between substance abuse and fetal health. In fact, "the information we have about the teratogenic effects of substance abuse during pregnancy tends to be sketchy and tainted, and there is much more to be learned." ${ }^{30}$ As noted by Rodgers:

There is little evidence that prenatal substance exposure, including exposure to tobacco, cocaine, marijuana, or alcohol, results in significant deficits when measured on standardized tests. Rather, low socioeconomic status directly correlates with performance deficits. Post-natal environments are crucial. ${ }^{31}$

It seems odd, to say the least, that such obviously relevant considerations should be completely absent from a judgment in a case involving a woman in whose life these factors are so clearly reflected. What we have, in Major J.'s dissent, is a judgment supporting coercive intervention in a pregnant woman's life based on incomplete scientific evidence (some of which was not proven at a trial but presented as argument on appeal) and which virtually ignores the broader social and environmental factors

There are eleven references to medical science, technology and/or medical knowledge in the course of Major J.'s decision; ten of those references are found in his 50-paragraph analysis: D.F.G., supra note 1 at paras. $67,92,102,105,107,109,110,112,114,120$, and 138. D.F.G., supra note $I$ at para. 88.

D. Mathieu, Preventing Prenatal Harm: Should the State Intervene? 2d ed. (Washington, D.C.: Georgetown University Press, 1996) at 113. See also: J.E. Bertin, "Regulating Reproduction" in J.C. Callahan, ed., Reproduction, Ethics, and the Law: Feminist Perspectives (Bloomington: Indiana University Press, 1995) 380 at 387-92; L.C. Mayes et al., "The Problem of Prenatal Cocaine Exposure: A Rush to Judgment" (1992) 267(3) J.A.M.A. 406; G. Koren et al., "Bias Against the Null Hypothesis: The Reproductive Hazards of Cocaine" (16 December 1989) 2 Lancet 1440; and S.J. Barton, R. Harrigan \& A.M. Tse, "Prenatal Cocaine Exposure: Implications for Practice, Policy Development, and Needs for Future Research" (1993) 15:1 J. of Perinatology 10.

$3 \quad$ S. Rodgers, "Juridical Interference with Gestation and Birth" in Research Studies of the Royal Commission on New Reproductive Technologies: Legal and Ethical Issues in New Reproductive Technologies: Pregnancy and Parenthood, vol. 4 (Ottawa: Minister of Supply and Services Canada, 1993) at 92. See also Mathieu, ibid. at 114: "[P]rincipal risk factors for low birth weight infants are the mother's low socioeconomic status, African descent, low level of education, unmarried status and age (under seventeen or over thirty four)." 
which are relevant to fetal health. ${ }^{32}$ This attitude seems particularly abhorrent in a country with inadequate prenatal and postnatal support mechanisms. ${ }^{33}$ As Christine Overall argues, "protecting and caring for the fetus means protecting and caring for the pregnant woman - through adequate housing, nutrition, education, medical care and freedom from physical and emotional abuse."

\section{The Evolution of Medical Technology: A REASON FOR MORE OR LESS REPRODUCTIVE AUTONOMY?}

Implicit in Major J.'s dissent is the suggestion that because we have the technology to do something, we ought to use it. Admittedly, this argument is intuitively attractive. If we have the knowledge and ability to intervene effectively and to prevent suffering, do we not have a moral responsibility to use that knowledge? Perhaps. ${ }^{34}$ However, the mere existence of increased information about fetal health, for example, does not render irrelevant the original ethical principles and social dilemmas which gave rise to existing social policy. Although we now have more information about the consequences of refraining from interfering with a pregnant woman's autonomy there may, on the whole, still be strong social policy reasons to retain the well established policy. In other words, the fact that science and technology may make the retention and application of a social policy more difficult, even heart-wrenching, does not, on its own, make that social policy wrong. And, while the result of a decision prohibiting intervention with the autonomy of a pregnant woman may "seem callous to the rights of fetuses since some fetuses that might be salvaged may die or be born defective," this alone may not justify the alternative.

[The death or disability of some fetuses] will be tragic, but it is likely to be rare. It is the price society pays for protecting the rights of all competent adults, and preventing forcible, physical violations of women by coercive obstetricians and judges. The choice between fetal health and maternal liberty is laced with moral and ethical dilemmas. The force of law will not make them go away. ${ }^{35}$

Indeed, as one author has noted, "[d]efining human sexuality and reproduction issues within a medical and scientific model ... has the subtle power of displacing an alternative focus on the social, economic, and environmental issues of reproduction." Woliver, supra note 21 at 347.

C. Overall, "Mother/Fetus/State Conflicts" (1989) 9 Health L. Can. 101 at 103; see also D. Johnsen, "A New Threat to Pregnant Women's Autonomy" (1987) 17:4 Hastings Cent. Rep. 33 at 39 . As noted by Rodgers, supra note 31 at 91 , "Concern about fetal welfare may reasonably be described as bizarre in a jurisdiction that makes only the most limited provisions for prenatal care, for post-natal and infant care, and for the provision of housing and nutrition for children after birth." It is interesting to note that around the time of the Supreme Court hearing, an aboriginal treatment centre in Manitoba (Selkirk Healing Centre) had to close 60 of its beds for adults and their dependant children as a result of lack of funds. Letter: Jean Doucha, Assistant Executive Director, The St. Norbert Foundation/Kirkos House (6 May 1997).

See, for example, Purdy, supra note 21 at 39-49, who argues that it is morally irresponsible to have a genetically disabled child.

G.J. Annas, "Forced Caesareans: The Most Unkindest Cut of All" (1982) 12:3 Hastings Cent. Rep. 17 at 45. 
Given the current "explosion in biomedical and reproductive technology,"36 Major J.'s reaction to "modern medicine" is particularly troubling. The rapid development of new and improved techniques for treatment of the fetus in utero means that it is not unrealistic to expect cases to come before the courts in which it is asserted that the pregnant woman's failure to consent to surgical intervention has endangered the life of her fetus. Does failure to consent to such intervention constitute "abuse"? Because Major J. makes no clear attempt to define the contours of his decision or to consider its implications, it is certainly arguable that refusal of this type of treatment could subject a pregnant woman to a court order for detention and forcible treatment. ${ }^{37}$ For Major J., the bottom line appears to be that a pregnant woman has two options: either abort the fetus, or submit to treatment and/or lifestyle recommendations made on the basis of "medical knowledge."

It is conceivable that Major J.'s approach could have relevance to issues that even he could not have been aware of. In the course of the ongoing "genetic revolution," 38 emerging technologies will continue to provide us with an expanding array of tests and interventions which will potentially allow future parents to know a vast amount about the "health status" of their future children. ${ }^{39}$ Genetic carrier testing currently allows parents to know their own genetic status and thus to make informed reproductive decisions (e.g., the chances of having a child affected by Tay Sachs disease or cystic fibrosis). Likewise, prenatal diagnosis (PND) allows pregnant women to learn of the presence of genetic anomalies which may cause, or be a risk factor associated with, a variety of disorders. ${ }^{40}$ How would Major J. apply such technologies? If it can be determined that a child may be "seriously and permanently impaired"41 as a result of a woman's actions or inaction vis-à-vis the new genetic technologies, would a court intervene? Admittedly, these examples are somewhat extreme, but they are nonetheless

Garcia, supra note 13 at $470-71$.

D.F.G., supra note 1 at para. 121; Major J. states that "It will only be in extreme cases, where the conduct of the mother has a reasonable possibility of causing serious irreparable harm to the unborn child, that a court should ... intervene." If refusal of consent to surgical treatment would cause "serious irreparable harm," it would seem that Major J. has left the door open to court intervention in that instance.

"Genetics: The Future is Now" Time (17 January 1995).

A vast amount has been written about the legal issues surrounding the new genetic technologies. For example, see: Ontario Law Reform Commission, Report on Genetic Testing (Toronto, 1996); T. Caulfield, ed., Special Edition: Professional Norms in the Practice of Human Genetics (1995) 3 Health Law Journal; B.M. Knoppers \& R. Chadwick, "The Human Genome Project: Under an International Ethical Microscope" (1994) 263 Science 2033; and Law Reform Commission of Canada, Human Dignity and Genetic Heritage (Ottawa, 1991).

For an example of the literature on the many ethical and policy concerns surrounding the use of PND, see M. Burgess, "Ethical Issues in Prenatal Testing" (1994) 27 Clinical Biochemistry 87; J. Botkin, "Fetal Privacy and Confidentiality" (1995) 25 Hastings Cent. Rep. 32; and M. Renaud et al., "Canadian Physicians and Prenatal Diagnosis: Prudence and Ambivalence" in Research Studies of the Royal Commission on New Reproductive Technologies: Current Practice of Prenatal Diagnosis in Canada, vol. 13 (Ottawa: Minister of Supply and Services Canada, 1993). Burgess, ibid. at 90 notes: "Appropriate use of such tests must be based on a careful and systematic study of the social contexts where the information is used, from the family to educational, health care, and employment settings."

D.F.G., supra note $I$ at para. 133. 
valid in that they illustrate the potential reach of Major J.'s conclusions, or, more to the point, the adoption of his conclusions by policy makers.

\section{CONCLUSION}

The rapid evolution of medical and scientific technologies that has characterized the 20 th century ${ }^{42}$ will no doubt continue; also undoubtedly, several such technologies will have significant implications for fetal health. It is neither possible nor desirable to disregard the inexorable progress of science, nor, however, should we embrace uncritically its apparent ability to simplify complex legal and social issues.

As is evident from the foregoing, we are of the view that decisions concerning the propriety of interference with the autonomy of a pregnant woman are best left to the legislature, involving as they do significant legal and social issues and conflicting values. This is not to say, however, that legislative intervention into the realm of reproductive decision-making is necessarily desirable. On the contrary, there are strong arguments which suggest that the continued evolution of medical technologies should not be permitted to erode the sphere of reproductive autonomy. Although extreme, the above-noted examples of new genetic technologies are useful in that they clearly demonstrate both the potential implications of Major J.'s reasoning and the danger inherent in relying wholeheartedly on scientific knowledge, particularly given the evolving and incomplete nature of that knowledge. The key to the responsible use of scientific knowledge and technological capacity lies in finding an appropriate balance among the interests of the state in preventing prenatal harm, the interests of the fetus and, most importantly, the interests of the pregnant woman.

In developing social and legal policy pertaining to maternal/fetal conflicts, we must recognize the importance of creating a thoughtful framework which will facilitate the integration of scientific and medical developments, while acknowledging and respecting the fundamental rights of individuals, particularly those of pregnant women. We must be ever mindful of the allure of science and careful to prevent a future wherein medicine becomes "...the new repository of truth, the place where absolute and often final judgments are made by supposedly morally neutral and objective experts." ${ }^{43}$ 